\title{
Insect pests of amaranthus and their management
}

\author{
Atanu Seni
}

Orissa University of Agriculture and Technology, AICRIP, RRTTS, Chiplima, Sambalpur-768025, Odisha, India

\begin{abstract}
Amaranthus (Amaranthus spp.) is one of the most popular leafy vegetables in India. They are grown widely as a source of grain and leafy vegetables. It is rich source of many essential micronutrients like carotene, vitamin $A, B, C$ and $D$, iron, calcium, amino acid like lysine and minerals especially iron, phosphorous and magnesium. But its production hampers due to the infestation of various insect pests namely Amaranth stem weevils: Hypolixus truncatulus (F.), H. nubilosus (B.), Beetworm Moth: Spoladea recurvalis (F.), Leafminer: Liriomyza huidobrensis (B.), Aphid: Myzus persicae S., Plant Bugs: Cletus sp., which ultimately affect the true potential of the crop. Here, the present article provides recent information regarding different insect pests of amaranthus, their identification, lifehistory, nature of damage and their management in an ecofriendly way.
\end{abstract}

Keywords - Amaranthus, insect pests, damage, management.

\section{INTRODUCTION}

Amaranthus (Amaranthus spp.; Family: Amaranthaceae) is grown mainly as a source of leafy vegetables and as a source of high-protein grain. The leaves are a rich source of calcium, iron and Vitamins A, B and C [4] whereas, grains are rich in dietary fiber, calcium and minerals such as iron, magnesium, phosphorus, copper and manganese and is a good source of essential amino acids especially lysine. It helps in lower blood pressure, cholesterol levels and improves the body's antioxidant status and immunity [6]. However, its production is affected by infestations of various insect pests that feed on various plant parts such as stems, leaves, flowers and seeds. A total of 92 insect pests belonging to 11 orders have been recorded from cultivated amaranthus [10]. Amaranth stem weevils: Hypolixus truncatulus (Fabricius), H. nubilosus (Boheman), Beet webworm Moth: Spoladea recurvalis Fabricius, Leafminer: Liriomyza huidobrensis Blanchard, Aphid: Myzus persicae Sulzer, Plant Bugs: Cletus sp., are some of important pests which cause damage in amaranthus plant. The infestation and intensity of damage caused by them varies from different crop growth periods, regions and seasons. So, it is very important to know the different insect pests of amaranthus, their identification, life-history, nature of damage and their management in an eco-friendly way for their sustainable productivity.

\section{MAJOR INSECT PESTS ATTACKING AMARANTHUS}

1. Amaranth stem weevils: Hypolixus truncatulus, H. nubilosus (Coleoptera: Curculionidae)

It is a major pest of the cultivated amaranthus, larvae tunnel the stems and adult feeds on tender leaves. The maximum number of adults recorded from a single plant ( $2.6 \mathrm{~m}$ height) is eight; however a maximum of 49 specimens at different stages of development recorded from a single plant, in the month of June-July. Percentage infestation varies from $35 \%$ to $81 \%$ at different regions in India [11].

Distribution: It is found in India, Mexico, Nigeria, South Africa and Kenya.

Host range: It is a polyphagous pest. Besides various species of Amaranthus it can infests large numbers of other host plants i.e. Acacia nilotica, Dalbergia sissoo etc. [11].

\section{Identification and life cycle:}

Hypolixus truncatulus adults are dark brown, variegated with white hairs and several dark patches of dense pubescence [11]. Body medium sized varying from 9.0 - 14.0 $\mathrm{mm}$ long and $3.0-4.0 \mathrm{~mm}$ wide. Females are slightly larger than males. Eyes are large, well developed, black, located at the base of rostrum on either side. Antennae are geniculate, fourteen segmented, present on either side of the snout arising from anterior one third of the snout. H. nubilosus adults are redish brown, variegated with white patches. Full grown larva are creamish white, apodous, C shaped grub.

Females lay oval, light yellowish eggs singly in excavated holes in stems, branches, petiole or midrib of the leaves. Egg period varies from 3-6 days in June-July. After egg laying holes were covered with the light green colour substances, secreted from the mouth. Hatching period is 3- 4 days and it takes almost 20-45 days to complete its 5 larval instars. After hatching, the larva begins to feed on the internal tissues, making its way into the stem in the form of an irregular zigzag tunnel, filling it with excreta as it bores down. They eaten up the pith region of the plant and go on tunneling downwards until fully fed and gets ready for pupation. Before pupation full grown larva bores its way up to the stem surface, where a small round hole is made leaving 
the thin epidermis layer intact. At the same place, subsequently the larva makes elongate oval pupal chamber which afterwards swells up and develops a large gall. Pupae are exarate, creamish white colour in the beginning but gradually turning into pale yellow. Pupal period lasts for 924 days and they completed at least three generations from April to November and total life cycle takes almost 58-64 days [11].

\section{Damage Symptoms:}

- Adults cause damage through feeding on the leaves, making irregular scratches on the tender stem and sometimes eating up all the inner contents of stem leaving behind only the epidermis and hypodermal tissues.

- Larvae cause damage through tunneling within the stems in a zig-zag way which reduces the vitality and vigour of the plants. Many such stems later rupture longitudinally thus exposing to the risk of desiccation; sometimes even 2-3 tunnels may be seen in transverse sections of the stem.

- At the places of pupal chamber, the stem walls become thickened so as to form galls. The adults emerge by biting holes through these galls. As a result, the stem becomes very weak and breaks down at such places during heavy winds; such plants often lie prostrate on the ground and dry up.

Management of stem weevils:

- Destroy all wild amaranthus plants in the vicinity.

- As soon as infestation is observed, remove and destroy promptly all the affected plants with grubs inside.

- Spraying with Neem seed extract $5 \%(\mathrm{w} / \mathrm{v})$ is helpful to reduce the pest infestation [10].

\section{Beet webworm, Spoladea recurvalis (Lepidoptera; Pyralidae)}

Distribution: It is present in tropical and sub-tropical regions of Asia, Africa and Australia. Host range: Other than amaranth, it attacks on beet, beans, spinach and several weed species i.e. Chenopodium album, Portulaca oleracea and Trianthema portulacastrum [7].

Identification and life cycle:

Adults are brown in colour with forewing is deep brown with broad white median band and hindwings is deep brown with a broad white median bar. Mature larva is greeninsh with transparent epidermis, head light yellowishbrown with many brown spots.
Female lays almost 200 flattened elliptical eggs singly or in small groups on the lower surface of leaves. It takes 7 days to hatch. The larval stage lasts for 3 to 4 weeks. The most voracious and damaging stage is the third instar larva which prefers tender leaf [1]. Just before pupation, mature larvae turn reddish in colour. The pupa is yellowish brown in colour and pupates inside cocoons just below soil surface. The pupal period lasts for 12 days and it produces many generations in a year.

\section{Damage:}

- Young caterpillars feed on epidermis and voraciously feed on the green matter.

- Older ones web the leaves together and feed within.

- Severe attack results in complete skeletonisation and drying up of the leaves within a short time.

\section{Management:}

- Plough around trees to expose and kill pupae

- Collect and destroy the caterpillars

- Conserve the parasitoids such as Trichogramma, Bracon, Apanteles, campoletis.

- Spray azadirachtin 0.03\% (300 ppm) @ 1000-2000 $\mathrm{ml}$ in 200-400 1 of water/acre or azadirachtin 5\% W/W neem extract concentrate @ $80 \mathrm{ml}$ in 1601 of water/acre.

\section{Leafminer: Liriomyza huidobrensis (Diptera; Agromyzidae)}

Distribution: The moth is found in America, Asia, Africa and the Oceania.

Host range: It is a polyphagous pest and is known to attack host plants from 14 different families, both cultivated and wild including amaranth. Other important hosts are faba beans, onions, melons, garlic and peas [7].

Identification and life cycle: Adults are small, greyishblack, compact-bodied, 1.3-2.3 mm in body length, 1.3-2.3 $\mathrm{mm}$ in wing length. Females are slightly larger than males. Initially maggots are colourless but later turning pale yelloworange in colour. It may be distinguished from other Liriomyza species by the head and leg yellow parts being a darker orange-yellow, the third antennal segments very dark, sometimes almost black on top, and the mesoplura is largely black.

They inserted almost 117-161 off-white, slightly translucent eggs just below the leaf surface. The number of eggs laid varies according to temperature and host plant. Hatching period is 2-5 days and the duration of larval development is generally 4-7 days. The larval stage consists of three larval instars. The larva leaves the plant to pupate and pupae may be found in crop debris or in the soil [8]. 
Females had an average longevity of 3-28 days; male longevity was 2-6 days. It takes almost 17-30 days to complete its life cycle during the summer and in 50-65 days during the winter [5].

Damage:

- Maggots produce the serpentine leaf mines which are usually white with dampened black and dried brown areas.

- Several larvae feeding on a single leaf may produce a secondary blotch like mine and leaf wilt may occur.

\section{Management:}

- Hand picking and destruction of infested leaves with maggots in early stages may be effective in reducing population built-up.

- Spray azadirachtin 0.03\% (300 ppm) @ 1000-2000 $\mathrm{ml}$ in 200-400 1 of water/acre or azadirachtin 5\% W/W neem extract concentrate @ $80 \mathrm{ml}$ in 1601 of water/acre.

\section{Aphid, Myzus persicae (Aphididae: Hemiptera)}

Distribution: It is distributed throughout the world except in areas with extreme temperatures or moisture.

Host range: It is a serious pest of amaranth, groundnuts, capsicums, carrots, maize, beans, potato, tomato and eggplants. Peach is its primary host for sexual reproduction in colder climates.

\section{Identification and life cycle:}

Nymphs are about $2 \mathrm{~mm}$ long, olive-green, resembling the parthenogenic females, which reach $2.5 \mathrm{~mm}$ in length. The apterate viviparous females are yellow-green, with 3 brown longitudinal lines, one at mid-dorsum the others on each side. The siphunculi are pale green, twice as long as the cauda, slightly swollen in their middle. The head, antennae, thorax and cauda of the alate females are dark.

In the cool regions sexual (amphigonic) females appear in the autumn and lay about a dozen fertilized eggs in crevices on their primary hosts, usually peaches. The eggs remain dormant during winter, hatching in the spring and the emerging nymphs feed on opening buds. They then initiate a few parthenogenic cycles of about two weeks each. Later in the season as host quality declines, alate forms appear and migrate to their diverse alternative ("secondary") host-plants, on which they establish colonies of apterate adults. A female may give birth to 75 young during its life. The nymphs moult five times to become adults in 8-12 days. Dry weather conditions are favorable to aphids whereas heavy rainfall decreases their numbers [2].

Damage:

- The damage is caused both by the nymphs and adults by sucking plant sap causing yellowing and drying of leaves.

- Severe infestation results in curling of leaves, stunted growth and gradual drying and death of tender region of the plants.

- They produce copious amounts of honeydew, which serves as a medium on which sooty mold grows. Sooty mold blackens the leaf and decreases photosynthetic activity of the plant [3].

- Seed production is hampered by aphid infestation where it may lead to deformed seeds, decreased flower and seed formation or reduced seed viability [9].

- It also transmits many important plant viruses such as such as Potato leaf roll virus (PLRV), Potato virus $\mathrm{Y}$ (PVY), Cucumber mosaic virus (CMV), and Pepper veinal mottle virus (PVMV).

Management:

- Destroy the infested plant parts.

- Follow clean cultivation.

- Conserve the Parasitoid, i.e. Aphidius colemani and Predators i.e. syrphid/hover flies, green lacewings (Mallada basalis and Chrysoperla carnea), predatory coccinellids (Stethorus punctillum) etc.

- Spray azadirachtin 5\% W/W neem extract concentrate@80 ml in 1601 of water/acre.

- Spraying of Verticillium lecanii @ $1 \times 10^{7}$ viable spores $/ \mathrm{ml}$, reduce the aphid population.

Beside the above mentioned major insect pests there are many minor insect pests causing damage to amaranthus crop at different region and growth stages of the crop.

The incidence of grasshoppers such as Atractomorpha crenulata (Pyrgomorphidae: Orthoptera) and Pyrgomorpha conica (Pyrgomorphidae: Orthoptera) also found on amaranthus. Both adults and nymphs feed on the leaves and cut the tender shoots.

The plant bug; Cletus sp. (Coreidae: Hemiptera) whose population often reaches peak during the critical milky seeds stage. It feeds on the seed causing discolouration, shriveling and premature dying of seeds thereby reducing seed yield and viability. 


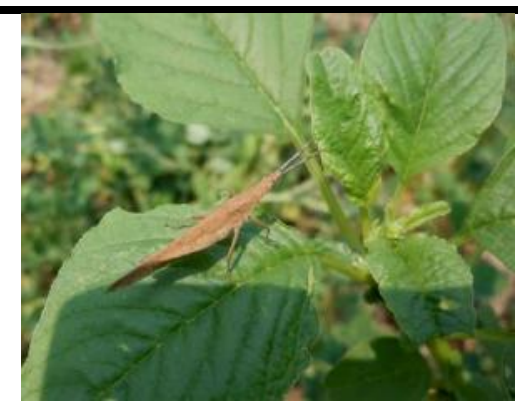

$\mathrm{A}$

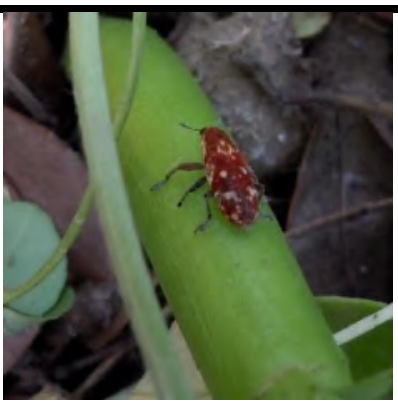

B

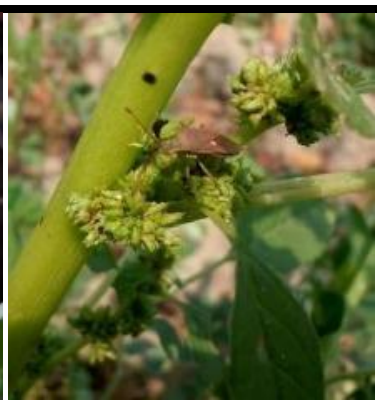

$\mathrm{C}$

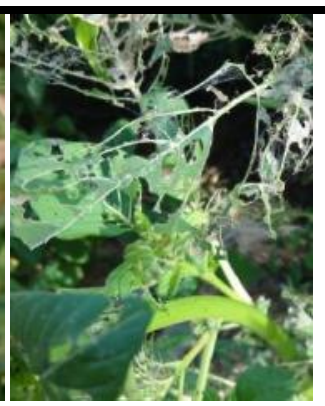

$\mathrm{D}$

Fig.1: Insects infesting amaranthus plant (Contai, West Bengal); A: Pyrgomorpha sp., B: Hypolixus nubilosus, C: Cletus sp., D: Webworm infested leaves

\section{CONCLUSION}

Importance should be given to sustainable production of amaranthus by managing the insect pests by integrating different easily available management practices including biological, cultural, mechanical and physical means. Further, care should be given to conserve the indigenous bio control agents.

\section{REFERENCES}

[1] Aderolu, I. A., Omooloye, A. A., Okelana, F. A. 2013. Occurrence, Abundance and Control of the Major Insect Pests Associated with Amaranths in Ibadan, Nigeria. Entomology, Ornithology and Herpetology, 2: 112. doi:10.4172/2161-0983.1000112

[2] Berim, M. N. 2015. Aphis craccivora Koch.-Groundnut Aphid. Interactive Agricultural Ecological Atlas of Russia and Neighboring Countries. AgroAtlas.

[3] Elmer, H. S. and Brawner, O. L. 1975. Control of Brown Soft Scale in Central Valley. Citrograph, 60(11): 402-403.

[4] Kagali, R. N. 2014. An integrated pest management approach of amaranth insect pests in Buuri District, Meru County, Kenya. M.S thesis submitted to Jomo Kenyatta University of Agriculture and Technology, Kenya.

[5] Lange, W. H., Gricarick, A. A. and Carlson, E. C. 1957. Serpentine leafminer damage. California Agriculture, 11:3-5.

[6] Martirosyan, D. M., Miroshnichenko, L. A., Kulakova, S. N., Pogojeva, A. V., Zoloedov, V. I. 2007. "Amaranth oil application for coronary heart disease and hypertension". Lipids in Health and Disease, 6: 1.

[7] Mureithi, D. M., Fiaboe, K. K. M., Ekesi, S., Meyhöfer, R. 2017. Important arthropod pests on leafy Amaranth (Amaranthus viridis, A. tricolor and A. blitum) and broad-leafed African nightshade (Solanum scabrum) with a special focus on host-plant ranges. African Journal of Horticultural Science, 11:1-17.

[8] Parrella, M. P., Bethke, J. A. 1984. Biological studies of Liriomyza huidobrensis (Diptera: Agromyzidae) on chrysanthemum, aster, and pea. Journal of Economic Entomology, 77(2):342-345.

[9] Picker, M., Griffiths, C. and Weaving, A. 2004. Field guide to insects of South Africa. South Africa: Struik Publishers. pp; 444.

[10] Rajeshkanna, S., Sivaraga, N. and Mikunthan, G. 2017. Biology and management Of Amaranthus stem borer (Hypolixus truncatulus) (Coleoptera: Curculionidae). Annals of Sri Lanka Department of Agriculture. 19: 258 $-266$.

[11] Tara, J. S., Azam, M., Ayri, S., Feroz, M. and Ramamurthy, V. 2009. Bionomics of Hypolixus truncatulus (Coleoptera, Curculionidae, Lixinae, Lixini), a major pest of Amaranthus caudatus L. Munis Entomology \& Zoology, 4(2): 510-518. 